\title{
Distance technologies in sustainable education: the case of Ukraine during the coronavirus pandemic
}

\author{
Oksana Poplavska ${ }^{1}$, Nataliia Danylevych ${ }^{1}$, Svetlana Rudakova ${ }^{1}$, and Liudmyla \\ Shchetinina ${ }^{1, *}$ \\ ${ }^{1}$ Kyiv National Economic University named after Vadym Hetman, Department of Personnel \\ Management and Labor Economics, 54/1 Prospect Peremogy, 03057 Kyiv, Ukraine
}

\begin{abstract}
Sustainable education systems in tertiary institutions aim to reduce the negative impact of the COVID-19 pandemic. To identify the readiness of educational institutions for current and future problems, a survey was conducted among a representative number of teachers and students. The purpose is to substantiate the importance of distance technologies for sustainable education in Ukraine. As the result, we'll have fine tools to select the best distance technologies for education that can fully support academic communication. The conducted studies allowed us to conclude that distance technologies expand the accessibility of sustainable education. However, we also The article identifies problems in the introduction of distance technologies into the system of sustainable education of a technical, organizational and psychological nature. However, the pandemic motivated teachers to actively explore the new possibilities of distance technologies, as well as to implement them in the educational process. The inclusion of online education into classical education makes it possible to expand competencies through specialized training and professional platforms, significantly improving the quality of education. A feature of the spread of distance technologies in Ukraine has become a one-time, large-scale implementation of them in the educational process, which ensures the stability of educational systems in the future.
\end{abstract}

\section{Introduction}

Information technologies have imperceptibly but firmly entered the daily life of every person. They have significantly changed everyone's lifestyle, motivating people to be more mobile and educated. They made it possible to quickly receive and process huge amounts of information. In this regard, business structures have already embraced the considerable advantages of information technology; the government is also gradually moving to online platforms, improving the accessibility of government services to consumers. And, of course, information technology gradually began to be introduced into the educational process. At the same time, at first, their use was caused by the need to increase the computer literacy of the population, and in particular young people, and then as an effective

\footnotetext{
*Corresponding author: sludval@ukr.net
} 
teaching tool. And today the majority of university professors cannot imagine conducting classes without the use of information technologies to some degree.

Information technologies are traditionally used in the educational process at Ukrainian universities to visualize the educational material of various processes, conduct monitoring, and teach students the basics of working with professional software products. Separately we need to highlight distance education, which has been developing for less than 10 years. During this period, universities have accumulated some experience in using various information technologies, and the coronavirus pandemic has become a good test drive. As a result, some problem areas came forth, such as a stress test revealed a significant limitation of certain resources and a low readiness of most educational institutions to effectively use information technology tools. Therefore, it is important to study the challenges and opportunities of digitalization in order to respond quickly and adjust training programs and technologies to prevent a deterioration of the education level. This task directly reflects the Sustainable Development Goals, to which Ukraine is also a signatory.

\section{Literature review}

Taking into account the peculiarities of the handling of information by the modern generation of students, information technologies provide an important toolkit for increasing the efficiency of the processes of acquiring the necessary competencies. An important feature of information technologies is that they improve the quality of education. Many authors note that the content and relevance of training programs, social interaction directly depend on the availability of technical support $[1,2]$. The use of information technologies in teaching students in developing countries, including Ukraine, is especially relevant. As the researchers note [3], "the fundamental problem is that what strategies should be adopted so that education systems in developing countries do not only follow developed countries but grow and progress base on their own needs in the path of progress".

The need to expand learning with the help of online technologies is also determined by the fact that they provide students with wider opportunities to choose a course (the subject of study), a method of obtaining information and flexibility in terms of the time of work to consolidate knowledge and in dealing with the development of skills related to professional knowledge [4]. By choosing the most relevant tool from the entire spectrum of information technologies, it is possible to achieve the best results in the absorption of information and the acquisition of skills and competencies required by the labor market. For example, the use of chatbots facilitates communication between a teacher and a student [5], the introduction of Multimedia learning environments contributes to the dynamics of the learning process and motivates for better self-organization [6]. At the same time, information technologies by themselves cannot be a measure of the quality of education, it is important that experienced and knowledgeable teachers use this tool. the above is an obvious fact, though. Unfortunately, the beginning of 2020 was marked by the coronavirus pandemic, which made adjustments to the organization of the learning process around the world. The pandemic required the consolidation of the efforts of all mankind, so decisions were made to close educational institutions for visiting. Thus, life itself pushed the education sector to use information technologies more actively. As a result, countries that have already actively used information technologies have survived this difficult stage more easily, while others state that they are not ready to switch to online learning because it stays at a low level. In some countries, China, in particular, there was a boom in online learning [7], while in Ukraine most universities were not ready for such an event, as explained by the head of the Committee on Education of the Supreme Council of Ukraine [8], despite the fact that there are many educational platforms available on the Internet. 
At the same time, information and communication technologies should be considered as an element of the formation of a platform for sustainable education, since, on the one hand, their implementation is directed towards strengthening students' skills necessary for the labor market, and on the other, greater inclusion. For example, Spanish researchers confirm a direct relationship between the content of students' curricula and their level of preparation for achieving sustainable development goals [9], as well as the formation of a sustainable society through a sustainable education system [10]. Taking into account the results of the research $[11,12]$, it becomes obvious that there is a need to revise both the requirements for educational programs and technologies, with the help of which it is possible to implement sustainable education on a bigger scale. And in this context, the most problematic "zones" when using information and communication technologies are the possibilities of developing emotional intelligence, increasing the level of social responsibility, and the security of communications. In some areas of training specialists, there is a need to update the content in terms of introducing new approaches to determining efficiency and productivity. So, for some specialties, it becomes more important not only to take into account economic results but to assess their level of achievement of sustainable development goals (through the social, environmental block). As noted by researchers [13], education must be viewed through the prism of sustainable development and take into account the potential of distance learning [14].

\section{The goal and hypotheses of the research}

The purpose of the article is to substantiate best approaches to the choice of information technology tools used for the training of students, which allow building better communication, especially feedback, and developing a plan for the adaptation of the educational system to the pandemics to ensure sustainable education. As hypotheses, the authors put forward the following statements: 1) the choice of information tools for teaching students depends on the objective (the quality of the training tool, compliance with the learning objectives, the availability of technical means, the sufficient level of proficiency (ability to work) with these tools) and subjective (the willingness to work with a specific information environment/platform; the motivation of participants in the learning process, self-organization and responsibility) factors; 2) the sustainability of training, the effectiveness of the use of various information technologies significantly depends on the ability to build channels of fast and adequate communication; 3) the use of information technology in teaching students requires a balanced decision and consistent actions (that is, the implementation of a comprehensive program that includes informational support for participants in the process).

\section{Research methodology}

In Ukraine, the existing definition of information technology in education implies the use of digital communication tools, as well as special software products for the acquisition of professional skills for future work in automated management systems of various organizations. That is, the training of students takes place in the form of contact classes, where digital technologies, means of communication, and visualization are the tools for displaying the material or assessing the level of mastering knowledge. Besides, distance learning, which is regulated at the legislative level, and platforms for self-education, which are a private initiative of groups of enthusiasts, are separated. Thus, based on the purposes of the information resources usage and communication channels, the authors identified the following groups of information technologies: 
Group 1 "Multimedia". The purpose of these technologies is visualization and knowledge transfer.

Group 2. "Tools for the learning results assessment." The purpose of these technologies is to assess the level of understanding and knowledge of students.

Group 3. "Communication". The purpose of these technologies is the communication, research discussions, discussions of the learning results, distribution of the information in the professional sphere.

Group 4. "Educational platforms". The purpose of these technologies is to provide information resources for the independent mastering of knowledge.

Group 5. "Distance courses". The purpose of these technologies is to accompany the students during their training (mastering knowledge and professional skills in selected disciplines), obtaining an academic education.

Based on the accepted classification, to achieve the designated goals, the authors conducted a comparative analysis of the information technologies used in Ukraine, and as the result, and were able to highlight the most important tools.

The conducted research with the help of focus groups among students and teachers made it possible to describe and identify the main problem areas in teaching using information technologies as well as detail the most important directions for improving the communication of the parties in the learning process.

The conducted content analysis of various educational platforms helped to identify the strengths and weaknesses of these platforms and made it possible to qualitatively assess the effectiveness of the platforms, and to develop recommendations for their use in various conditions.

\section{Results and discussion}

In the article, the authors present summarized data that allow a comprehensive assessment of the level of distribution of the usage of information technologies in teaching students, the adequacy and quality of their use.

\subsection{Practices of the implementation and usage of distance learning}

The legislative basis for the introduction of distance learning was the relevant order of the Ministry of Education of Ukraine. According to it, distance learning is possible not only in universities but also in schools and vocational institutions. At the same time, the introduction of such a form is possible only after obtaining permission from the Ministry of Education of Ukraine. However, the lack of technical, personnel and financial support hinders the development of distance education. Therefore, most of the universities that have introduced distance learning consisted of institutions with a humanitarian bias that train economists and managers [15]. In addition, the state provides for the use of one platform for distance learning - Moodle. This regulation of the issue has led to the fact that distance learning is officially allowed only in 15 educational institutions (this is less than $2 \%$ of all institutions of higher education).

Considering the practice of using this platform during the coronavirus pandemic (on the example of the Vadim Hetman Kyiv National Economic University), the authors noted the following: the number of teachers who used this platform for teaching students was less than $50 \%$ of the total number of teachers and the already developed courses or their modules (for example, for testing the level of the students' knowledge) were used most often. Unfortunately, some leading universities in Ukraine did not provide distance learning platforms, which did not allow them to quickly engage in remote work and narrowed (initially) the possibilities of high-quality online education during the quarantine period. 
As we mentioned, academic distance education for students stays underdeveloped in Ukraine. And one of the reasons is the lack of supply of these services among universities. This situation is partly dictated by imperfect legislation (as described above), and, on the other hand, by low trust in it among the population. Full-time education remains traditional (including the part-time form, which involves conducting contact classes in classrooms).

\subsection{The quality of maintained communication}

The sustainability of the educational process in higher education institutions should reduce the impact of the COVID-19 pandemic on learning, and ensure its preparedness for future crises related to the spread of online studies. To identify the readiness of educational institutions for the current and future problems, a survey was conducted among a representative number of teachers and students.

The spread of the coronavirus in Ukraine led to the introduction of quarantine in March 2020 , which inevitably affected the higher education system in the country. Teachers and students were forced to master new remote technologies in a short time. That is, the spread of coronavirus was the impetus for the implementation of remote technologies and various applications in the education system. Maintaining the high quality of educational services required changes in the technology for conducting classes with students online and mastering new software products for the parties to the educational process. At the beginning of the quarantine, the selection of distance technologies by teachers depended on their awareness and expertise. The most popular remote technologies were E-mail, Viber, and Telegram (Fig. 1). But the use of only these remote technologies did not provide the required quality of educational services.

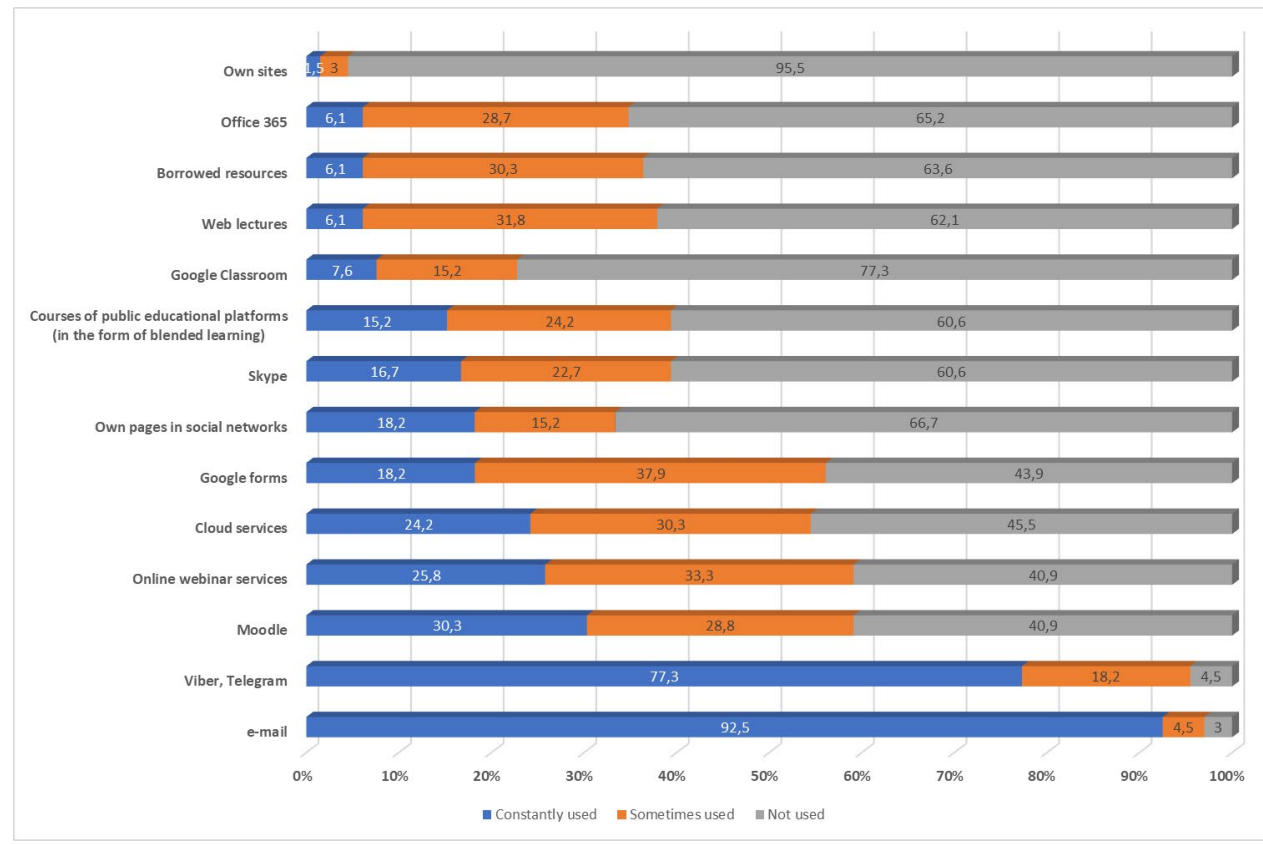

Fig. 1. The results of the survey on the used distance learning technologies to ensure the teaching of academic disciplines during the quarantine.

In addition to insufficient expertise in the use of distance technologies by teachers, respondents indicated other problems (Fig. 2): 
1. Technical: Lack of proper technical equipment; Inconvenience of using distance learning platforms; Lack of constant access to the Internet; the difficulty of adapting the discipline for distance learning.

2. Psychological: Students' unwillingness to perform the set tasks; Lack of appropriate incentives for the use of distance learning technologies.

3. Organizational: Irregularity of communication with students; Lack of appropriate educational materials to ensure distance learning of disciplines; Lack of appropriate skills to work with distance learning technologies.

The presence of these problems reduces the quality of the educational process, so the efficiency of the solutions to them determines the results of higher education institutions. The educational process must meet the needs of all its subjects - students, teachers, and administration of the educational institution. Only in this case, educational activities will meet the goals of sustainable development of the country.

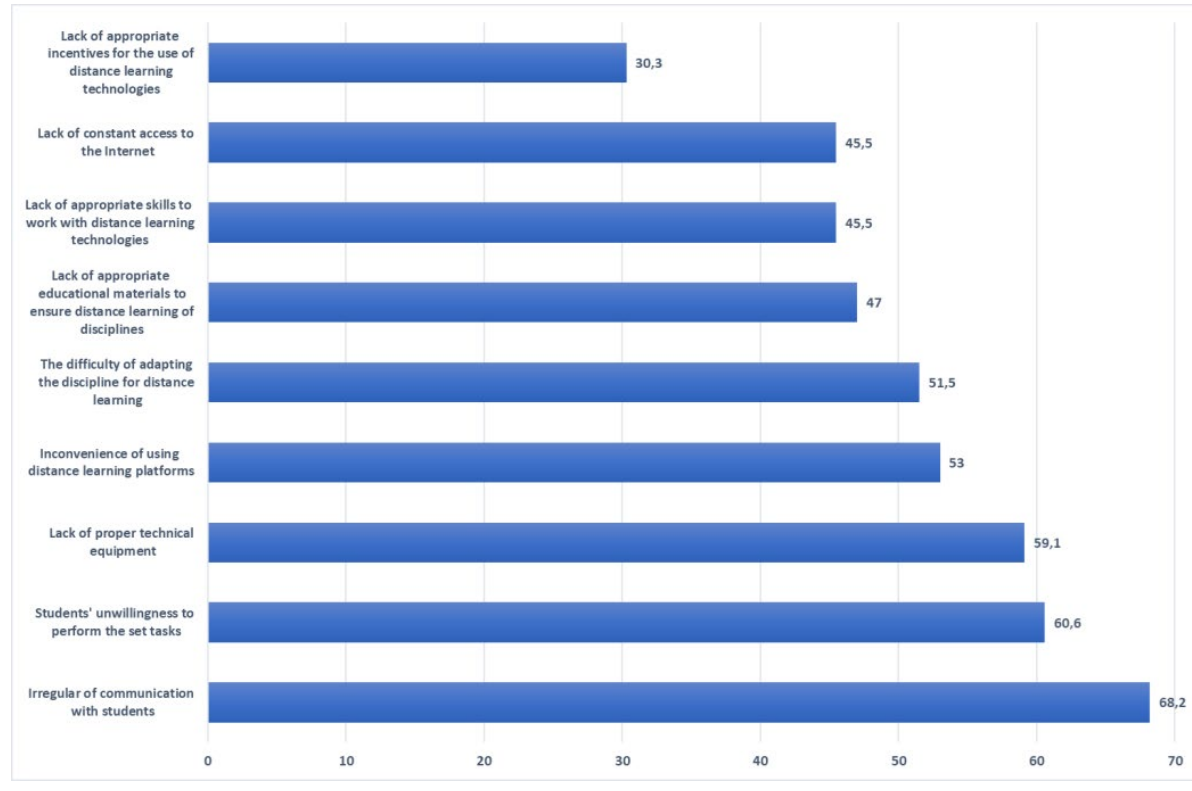

Fig. 2. The results of the survey among teachers on the problems that arose during the teaching of academic disciplines with the use of distance technology.

In the 2020-2021 academic year, teachers began to actively conduct classes using Zoom, Meet, Moodle, Google Classroom. At the same time, the effectiveness of the educational process depends not only on the readiness of teachers but also on students. The most common distance learning tools, according to a survey of students, were Zoom, Moodle, and Meet (Fig. 3). These remote technologies differ in their functionality. For example, Moodle differs from Zoom and Meet in that the teacher and the student do not communicate in real-time, the student completes the task at a convenient time. Therefore, the efforts of a teacher who uses Zoom and Meet cannot be compared to the efforts of a teacher who prefers Moodle. Such differences should be taken into account when regulating the technologies for conducting classes with students, the motivation of teachers based on the results of taught disciplines, as well as when assessing the students' reaction. 


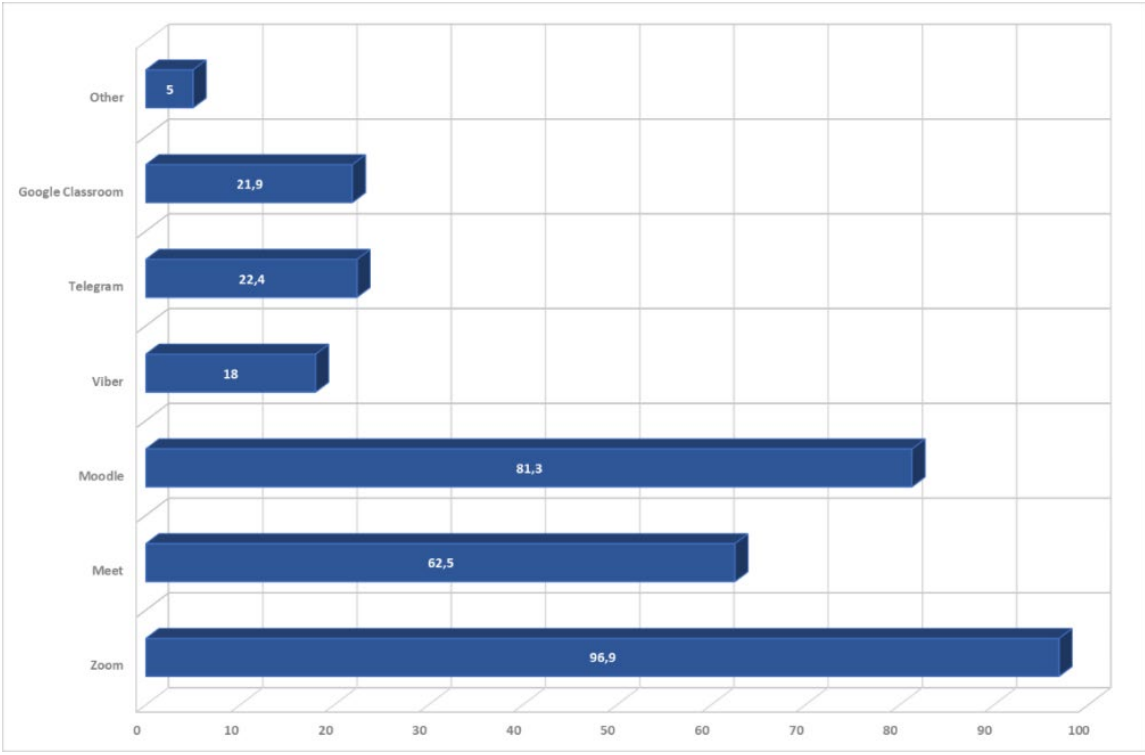

Fig. 3. The results of the survey among students on the distance learning technologies, which were used during the quarantine.

To assess the quality of the educational process online, special criteria should be used that differ from those used during traditional learning (Fig. 4).

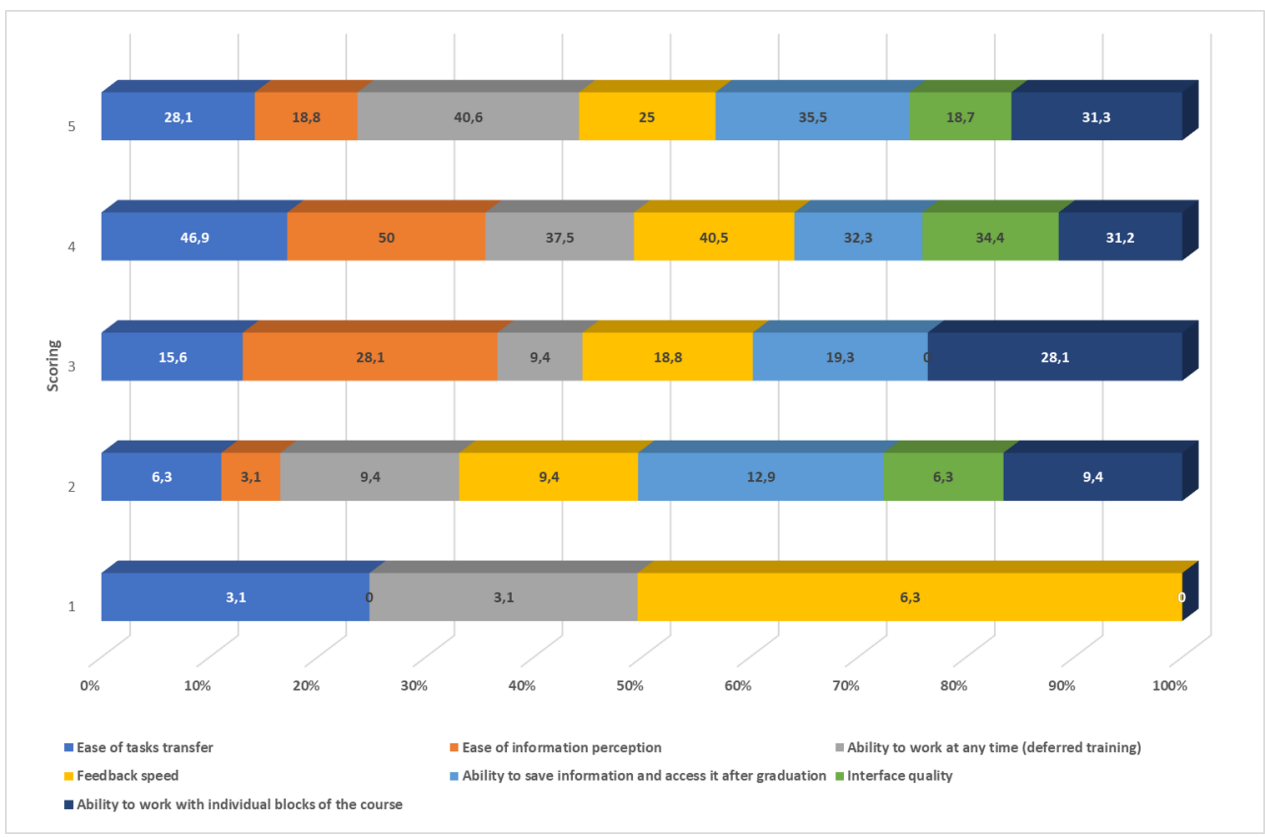

Fig. 4. The results of the evaluation of the quality of the educational online program by the students according to the various criteria.

According to the survey, the highest average score of students set the criterion "Ability to work at any time (deferred training)" - 4,031 points. However, it is possible to maintain and increase the value of this criterion only in distance learning. In full-time education 
improving the quality of this criterion can mean a significant reduction in other learning criteria quality. High average scores were also given by students to such criteria as "Ease of tasks' transfer" (3,906 points) and "Ability to save the information and access it after graduation" (3,904 points). The quality of online learning according to these two criteria can be improved through the pedagogical skills of the teachers, mastering by them of various computer applications as well as planning the structure of classes with students.

Additionally, according to students, the quality of online learning should be assessed by such criteria as the relevance of information; the convenience of remote technology and its communicative capabilities; computer literacy of the teacher; optimal time distribution; quick feedback; availability, and completeness of information; the possibility of combining different types of educational activities. The analysis of the criteria proposed by students makes it possible to conclude that the quality of the educational process, as in the case of traditional learning, will depend on the teacher. Only two of the proposed criteria are relevant to the features of remote technology - the convenience of remote technology and its communicative capabilities, and the possibility of combining different types of educational activities.

Distance learning technologies should take into account the characteristics of academic disciplines, the distribution of teaching hours between interactive and independent work of students. Students were asked to assess the level of compliance of distance learning technology with the needs of the discipline, where 0 is not suitable for learning; 5 - best meets the needs. According to the evaluation results, the following results were obtained (Fig. 5).

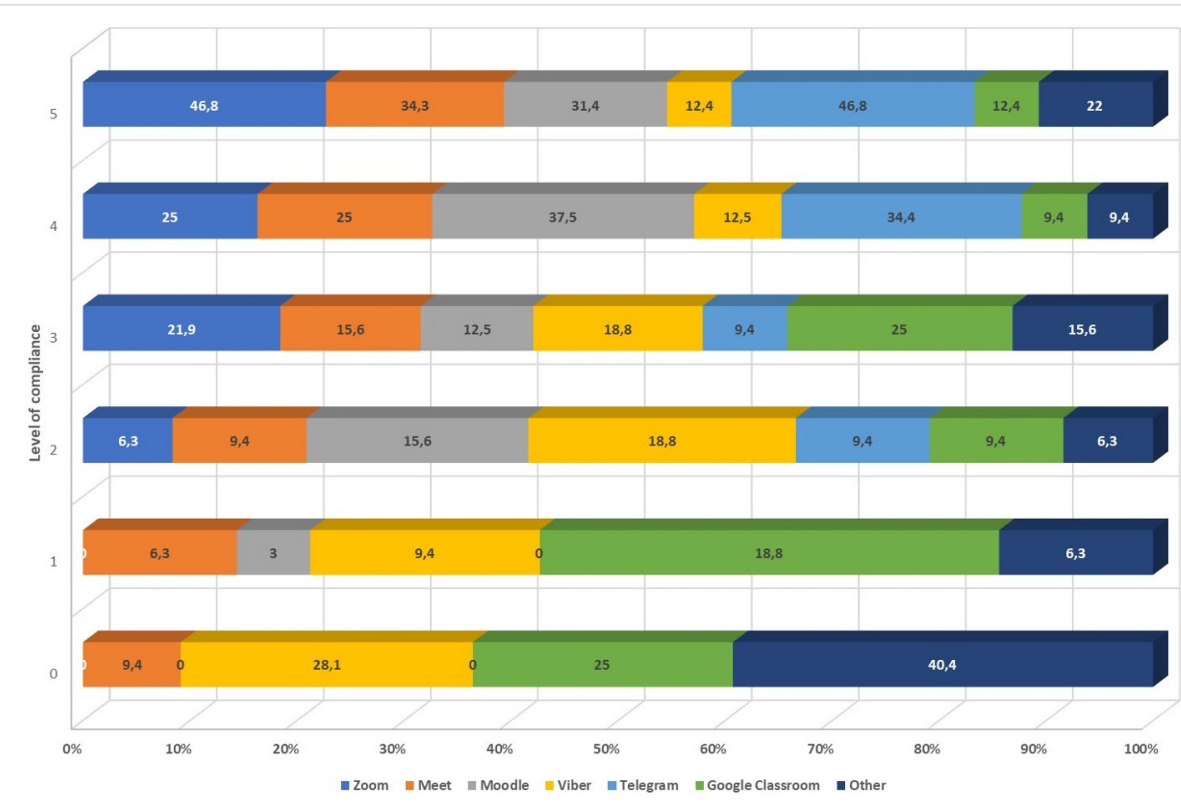

Fig. 5. The results of the assessment of the level of compliance of distance learning technologies with the needs of the discipline by students.

The first place among remote technologies working in real-time is Zoom. Zoom provides productive interaction between teacher and students, is easy to use, and has a built-in scheduler and tools for storing information. The program works on any device, the connection is more stable than in similar services. The disadvantage of using Zoom is its requirements for payments or the need to interrupt the session every 40 minutes of its use. 
Among communication channels, students preferred Telegram, which corresponds to the general trends of its popularity among young people.

Quality education is a key factor for sustainable development itself. It provides for the development of competencies that allow a person to analyze their actions in terms of their social, cultural, economic, and environmental impact on the present and future. Moreover, as sustainable education should not be limited to the university level, students are actively studying various subjects on different online platforms. Today, there are many online learning platforms for non-academic education. They exist both on a paid and free basis. Free content is attracting many students since they are focused on such refresher courses without increasing the financial burden. Among this category of platforms for distance education, the most popular domestic and international projects were identified (Table 1).

Table 1. Analysis of the most popular platforms for distance learning.

\begin{tabular}{|c|c|c|c|c|}
\hline $\begin{array}{l}\text { Name of } \\
\text { platform }\end{array}$ & Areas of studies & Project partners & Finances & Comments \\
\hline Prometheus & $\begin{array}{l}\text { Foreign language, public } \\
\text { education, } \\
\text { entrepreneurship, } \\
\text { pedagogy }\end{array}$ & $\begin{array}{l}\text { National University } \\
\text { of "Kyiv-Mohyla } \\
\text { Academy", Taras } \\
\text { Shevchenko } \\
\text { National University } \\
\text { of Kyiv, National } \\
\text { Technical University } \\
\text { of Ukraine } \\
\text { "Igor Sikorsky Kyiv } \\
\text { Polytechnic } \\
\text { Institute", Ukrainian } \\
\text { Catholic University } \\
\text { and Lviv IT School }\end{array}$ & $\begin{array}{l}\text { Free } \\
\text { education } \\
\text { project for } \\
\text { all }\end{array}$ & $\begin{array}{l}\text { Provides an } \\
\text { opportunity for } \\
\text { advanced } \\
\text { training for } \\
\text { teachers }\end{array}$ \\
\hline Coursera & $\begin{array}{l}\text { There are courses available } \\
\text { in many languages. Some } \\
\text { of the courses' topics are } \\
\text { Arts and Humanities, } \\
\text { Business, Computer } \\
\text { Science, Data Science, } \\
\text { Information Technology, } \\
\text { Health, Math and Logic, } \\
\text { Personal Development. }\end{array}$ & $\begin{array}{l}140 \quad \text { universities } \\
\text { from } 28 \text { countries }\end{array}$ & $\begin{array}{l}\text { free and paid } \\
\text { courses }\end{array}$ & $\begin{array}{l}\text { Courses are } \\
\text { taught by the } \\
\text { best teachers } \\
\text { from } \\
\text { universities and } \\
\text { world-class } \\
\text { companies. } \\
\text { Each course } \\
\text { takes } 4-6 \\
\text { weeks to } \\
\text { complete. }\end{array}$ \\
\hline eDX & $\begin{array}{l}\text { Over 2,500 courses on } \\
\text { different subjects including } \\
\text { Biology \& Life Sciences, } \\
\text { Architecture, Chemistry, } \\
\text { Art \& Culture, Electronics, } \\
\text { Education \& Teacher } \\
\text { Training, Medicine, Food } \\
\& \text { Nutrition, Physics, } \\
\text { Science, Music, Law, } \\
\text { History, Language, and } \\
\text { Environmental Studies. }\end{array}$ & $\begin{array}{l}\text { The company was } \\
\text { founded by Harvard } \\
\text { and MIT. }\end{array}$ & $\begin{array}{l}\text { free and paid } \\
\text { courses }\end{array}$ & $\begin{array}{l}\text { There are } \\
\text { courses for } \\
\text { introductory, } \\
\text { inter-mediate, } \\
\text { and advanced } \\
\text { levels. Any } \\
\text { edX course can } \\
\text { be downloaded } \\
\text { for offline } \\
\text { viewing. }\end{array}$ \\
\hline Udemy & $\begin{array}{l}\text { Udemy courses are divided } \\
\text { into } 13 \quad \text { different } \\
\text { categories: Finance \& } \\
\text { Accounting, Development, } \\
\text { Business, Marketing, IT \& } \\
\text { Software. }\end{array}$ & Business companies & $\begin{array}{l}\text { Each course } \\
\text { have to } \\
\text { purchased } \\
\text { individually }\end{array}$ & $\begin{array}{l}\text { The courses are } \\
\text { offered for all } \\
\text { levels. } \\
\text { Full life access } \\
\text { to course. }\end{array}$ \\
\hline
\end{tabular}


Each platform on the market offers its unique features and pricing, and each has its own strengths and weaknesses. The choice of a particular platform depends on the interest in academic courses or the purpose of taking them. Online course platforms vary where anyone can create and sell online courses of almost any quality (Udemy). Thanks to the pricing model proposed by Udemy, it may be the best option for those interested in learning specific skills rather than diving into a wide variety of fields. Coursera and eDX partner with educational institutions, provide students with access to academic courses and even offer a university degree for less than the usual cost of attending such courses or programs in person. The relevance of the online learning platforms usage is that they not only perform the functions of tools used to reach individual learning goals but also provide opportunities, completely new, for the development of skills through independent learning activities. The use of information technology in this process provides the opportunity to learn at a distance. This means that, unlike traditional forms of learning, in most cases, the student can choose the rhythm of work, as information databases and pages of educational platforms are available around the clock.

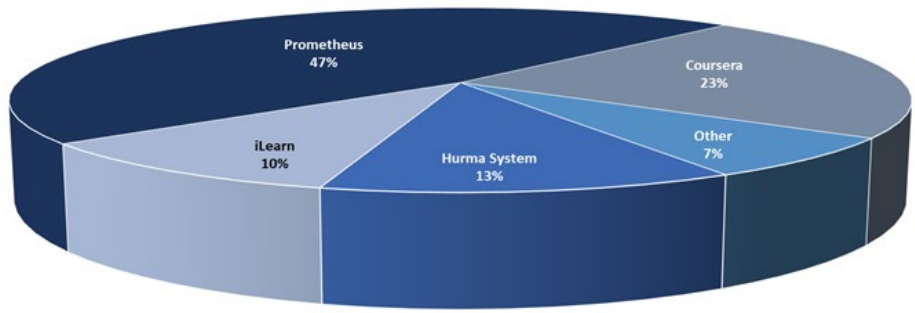

Fig. 6. The results of the survey among students on the choice of educational platforms.

Online learning platforms are a new way of organizing the learning process and offer alternatives and additions to traditional methods of its organization, creating opportunities for personal learning, group teaching, and interactive classes.

According to the results of the sociological survey, the respondents are most informed about the Prometheus platform (Fig. 6). The platform provides opportunities to listen to the best courses from leading teachers, universities, and organizations around the world and is free. Course subjects are divided into many conceptual clusters to increase the likelihood that the recommendation will be relevant to students.

Prometheus is also the most popular educational platform for use in online learning (Fig. 7).

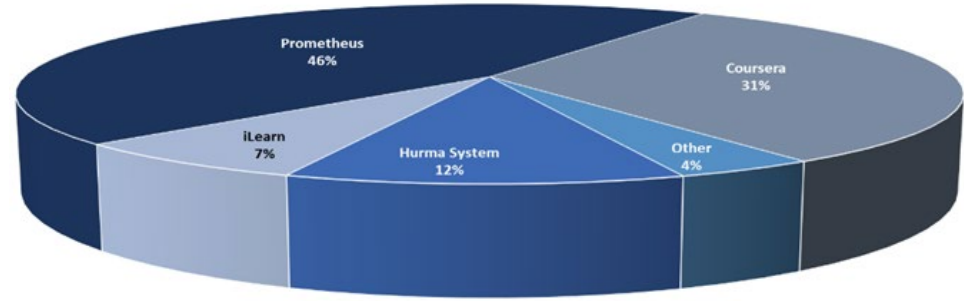

Fig. 7. The results of the survey among students on the learning experience through educational platforms. 
Second place goes to Coursera. Today, the Coursera platform offers "Learning Paths", thus trying to bring its products closer to the goals of professional students, directing those who know exactly what they want to learn, to the necessary courses. And in the absence of a specific goal, the platform is trying to pave the way for mastering the subject. It uses the master's approach - learning focused on the full mastery of the material and is designed for full-time, distance, and combined education. Coursera collaborates with universities around the world to deliver the courses of these educational institutions online. Different principles are used for this: gamification, interactive testing, online support of students. An important issue is the effectiveness of online courses on the educational platforms and teaching these courses online by teachers of higher education institutions (Fig. 8). Students rated the effectiveness of learning on the educational platforms with an average score of 3.73, while the effectiveness of education at their universities, according to their opinion, is 4.28 points. That is, the format of teaching in higher education is more attractive to students than learning through educational platforms. At the same time, one should take into account the fact that university education and education with the help of the educational platforms have their segments to provide educational services.

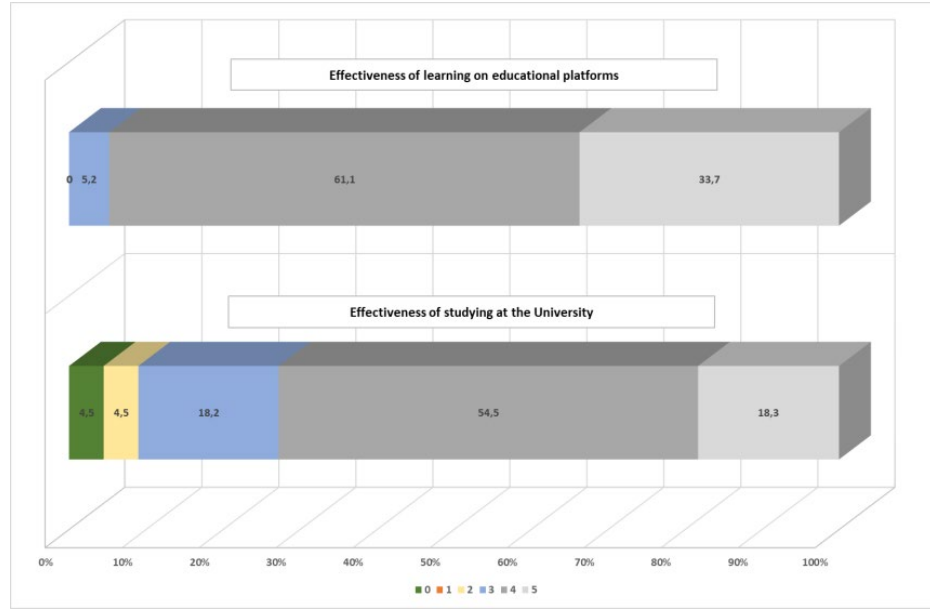

Fig. 8. Results of the survey among students on the effectiveness of learning through educational platforms and in higher education institutions.

\section{Conclusions}

The study contributes to the fact of the importance of sustainable education, on the one hand as a process of continuous quality education in conditions of uncertainty and challenges, and on the other as a tool for the acquiring of knowledge, behavioral attitudes of students to promote and implement the goals of sustainable development. It is important to note that in many respects movement in the indicated directions presupposes updating the content of the material, which is studied in conjunction with the use of modern distance learning technologies. Developing a future-oriented mindset is a key task of education. Ideas and principles of sustainable development are implemented in the professional activities of citizens, in the system of advanced training and professional retraining. The student must not only get a scientific and applied base, as is now accepted in modern high school but also be integrated into the modern world, be able to navigate in a variety of new knowledge areas and technologies. 
As the studies show, the correct choice of tools (among distance technologies) in accordance with the goals and objectives, allows you to improve the quality of education, facilitates the process of consolidating knowledge and competencies required for sustainable development, and thereby, forms sustainable education itself. At the same time, it was noted that sustainable education puts forward many requirements for every subject and object of the educational process. Therefore, the student must be motivated and organized, learn to control the learning process independently, especially when studying online.

\section{References}

1. Qiyun, W. (2008). A generic model for guiding the integration of ICT into teaching and learning November 2008 Innovations in Education and Teaching International, 45(4), 411-419.

2. Luchaninova, O., Koval, V., Deforzh, H., Nakonechna, L. \& Golovnia, O. (2019). Formation of communicative competence of future specialists by means of group work. Espacios, 40 (41), 11.

3. Hamidia, F., Meshkat, M., Rezaee, M., \& Jafari, M. (2011) Information Technology in Education December 2011 Procedia Computer Science, 3, 369-373.

4. Manganello, F., Falsetti, C., \& Leo, T. (2019). Self-Regulated Learning for WebEnhanced Control Engineering Education. Educational Technology \& Society, 22 (1), 44-58.

5. Lin, M. P-C., \& Chang, D. (2020). Enhancing Post-secondary Writers' Writing Skills with a Chatbot: A Mixed-Method Classroom Study. Educational Technology \& Society, 23 (1), 78-92.

6. Ting, Y.-L., Tai, Y., Tseng, T.-H., \& Tsai, S.-P. (2018). Innovative Use of Mobile Video Conferencing in Face-to-Face Collaborative Science Learning: The Case of Reflection in Optics. Educational Technology \& Society, 21 (3), 74-85.

7. Kandri, S-E. (2020). The COVID-19 pandemic has changed education forever. World Economic Forum.

8. Babak, S. (2020). Ukraine is technologically not ready until the new distance is overwhelmed. Radyo svoboda. https://www.radiosvoboda.org/a/news-babak-osvitadystantsiyne-navchannia/30701138.html

9. Sánchez-Carracedo, F, Moreno-Pino, FM, Romero-Portillo, D, \& Sureda, B. (2021) Education for Sustainable Development in Spanish University Education Degrees. Sustainability, 13(3), 1467. https://doi.org/10.3390/su13031467

10. Jiménez-Pérez, E, de Vicente-Yagüe Jara, M-I, Gutiérrez-Fresneda, R, \& GarcíaGuirao, P. (2021). Sustainable Education, Emotional Intelligence and Mother-Child Reading Competencies within Multiple Mediation Models. Sustainability, 13(4), 1803. https://doi.org/10.3390/su13041803

11. Chaleta, E, Saraiva, M, Leal, F, Fialho, I, \& Borralho, A. (2021). Higher Education and Sustainable Development Goals (SDG) - Potential Contribution of the Undergraduate Courses of the School of Social Sciences of the University of Évora. Sustainability, 13(4), 1828. https://doi.org/10.3390/su13041828

12. Petrova, M., Koval, V., Tepavicharova, M., Zerkal, A., Radchenko, A., \& Bondarchuk, N. (2020). The interaction between the human resources motivation and the commitment to the organization. Journal of Security and Sustainability Issues, 9(3), 897-907. https://doi.org/10.9770/jssi.2020.9.3(15)

13. Soomro, S.A., Casakin, H., Georgiev, G.V. (2021). Sustainable Design and Prototyping Using Digital Fabrication Tools for Education. Sustainability, 13(3), 1196. https://doi.org/10.3390/su13031196 
14. Ministry of Education and Science of Ukraine (n.d.). Educational institutions that enable remote study. Educational institutions that provide the opportunity to study remotely. https://mon.gov.ua/ua/osvita/visha-osvita/distancijna-osvita/navchalni-zakladiyaki-nadayut-mozhlivist-navchatis-viddaleno

15. Hollenbeck, B., Shi, Q. (2021). Developing Effective and Sustainable Distance Education Programs and Courses. International Journal of Information and Education Technology, 11(2), 102-106. http://www.ijiet.org/vol11/1496-L0020.pdf 